AGREGAT: Jurnal Ekonomi dan Bisnis

Vol. 2, No. 2, September 2018

http://journal.uhamka.ac.id/index.php/agregat

p-ISSN: 2580-3360 e-ISSN: 2581-2874

DOI: 10.22236/agregat_vol1/is4pp399-411

Hal 399-411

\title{
STANDAR AKUNTASI KEUANGAN ENTITAS TANPA AKUNTABILITAS PUBLIK (SAK ETAP)
}

\author{
Budiandru $^{1}$, Shabrina Saufani Isfa ${ }^{2}$ \\ ${ }^{12}$ Universitas Muhammadiyah Prof. DR HAMKA \\ Email: ${ }^{1}$ budiandru@gmail.com, ${ }^{2}$ shabrina@gmail.com
}

Diterima: 3 Juni 2018; Direvisi: 7 Juni 2018; Disetujui: 25 Juni 2018

\begin{abstract}
This study aims to analyze the application of SAK ETAP on the presentation of financial statements CV SK. CV SK is a medium-sized businesses engaged in catering services and Wedding Organizer. The method used in this research is descriptive qualitative analysis. The results of the study based on Balance Sheet and Income Statement for 2012-2016, show that the company has not presented cash flow statement, and notes to financial statements (CALK) and inconsistency in the presentation of some post on Balance Sheet not disclosed in CALK. This research suggests that companies develop other components of financial statements and disclose the company's accounting policies in CALK.
\end{abstract}

Keywords: Financial Statement, UMKM, SAK ETAP

\begin{abstract}
Abstrak
Penelitian ini bertujuan untuk menganalisis penerapan SAK ETAP pada penyajian laporan keuangan CV SK. CV SK merupakan usaha menengah yang bergerak di bidang jasa catering dan Wedding Organizer. Metode yang digunakan dalam penelitian ini adalah analisis deskriptif kualitatif. Hasil penelitian berdasarkan Neraca dan Laporan Laba Rugi tahun 2012-2016, menunjukan bahwa perusahaan belum menyajikan laporan arus kas, dan catatan atas laporan keuangan (CALK) serta terjadi inkonsistensi dalam penyajian beberapa pos pada Neraca yang tidak diungkapkan dalam CALK. Penelitian ini menyarankan agar perusahaan menyusun komponen laporan keuangan lainnya dan mengungkapkan kebijakan akuntansi perusahaan dalam CALK.
\end{abstract}

Kata Kunci: Laporan Keuangan, UMKM, SAK ETAP 


\section{PENDAHULUAN}

Salah satu jenis usaha di Indonesia adalah Usaha Kecil dan Menengah (UKM). Usaha Kecil dan Menengah (UKM) ini mempunyai peranan yang sangat penting bagi kondisi perekonomian negara Indonesia. Laporan keuangan perusahaan yang utama menyediakan informasi mengenai laporan laba rugi perusahaan dan laporan posisi keuangan.

Ikatan Akuntan Indonesia telah menerbitkan Standar Akuntansi Keuangan untuk Entitas Tanpa Akuntabiltas Publik (SAK-ETAP). SAK-ETAP ini telah berlaku efektif sejak 1 Januari 2011, sehingga perusahaan kecil seperti UKM tidak perlu membuat laporan keuangan dengan menggunakan PSAK umum yang berlaku. Di dalam beberapa hal SAKETAP memberikan banyak kemudahan untuk perusahaan dibandingkan dengan PSAK dengan ketentuan pelaporan yang lebih kompleks. Sesuai dengan ruang lingkup SAK-ETAP maka Standar ini dimaksudkan untuk digunakan oleh entitas tanpa akuntabilitas publik. Entitas tanpa akuntabilitas publik yang dimaksud adalah entitas yang tidak memiliki akuntabilitas publik signifikan dan tidak menerbitkan laporan keuangan untuk tujuan umum (general purpose financial statement) bagi pengguna eksternal. Dalam penyusunan laporan keuangan harus sesuai dengan prinsip-prinsip akuntansi. Penyusunan laporan keuangan disiapkan mulai dari berbagai sumber data. Data yang asli bukan saja digunakan untuk mengisi buku perkiraan, tetapi dapat juga dipakai untuk membuktikan keabsahan transaksi. Penyusunan laporan keuangan pasti selalu menghadapi kendala-kendala yang dialami. Seperti tidak lengkapnya buktibukti transaksi saat menyusun laporan keuangan, kesalahanan pencatatan pos-pos transaksi secara signifikan, yang sebelumnya sudah ditentukan karena terdapat biaya-biaya tak terduga selama operasi.

Oleh karena itu, suatu laporan keuangan perlu dilakukan pemeriksaan apakah dalam pembuatan laporan keuangan telah sesuai dengan PSAK yang berlaku di Indonesia, agar informasi keuangan yang disajikan di dalam laporan keuangan bersifat adil (fair) bagi semua pihak yang berkepentingan (manajemen, pemegang saham, pemerintah, dan kreditur). Hal ini melibatkan Kantor Akuntan Publik (KAP) sebagai pihak ketiga yang memberikan jasa akuntansi, salah satunya yaitu accounting service sekaligus untuk mengetahui dan 
401 AGREGAT: Jurnal Ekonomi dan Bisnis

Vol. 2, No. 2, September 2018

http://journal.uhamka.ac.id/index.php/agregat

p-ISSN: 2580-3360 e-ISSN: 2581-2874

DOI: 10.22236/agregat_vol1/is4pp399-411

Hal 399-411

menghimpun data perusahaan secara

financial statement) bagi pengguna lengkap dan akurat. Berdasarkan uraian eksternal. Contoh pengguna eksternal yang telah dikemukakan diatas, maka adalah pemilik yang tidak terlibat dapat dirumuskan masalah dalam langsung dalam pengelolaan usaha, penelitian ini yaitu "Bagaimanakah kreditur, dan lembaga pemeringkat kredit. penyusunan dan penyajian laporan keuangan CV SK berdasarkan SAK Menurut Walter, et,al., (2011), "Laporan ETAP”. Adapun penelitian ini dibatasi pada masalah penyusunan laporan keuangan, kendala-kendala yang dihadapi dalam menyusun laporan keuangan dan penyajian laporan keuangan neraca dan laba rugi tahun 2012-2016 menurut SAK ETAP 2016. Menurut Ryan Arie keuangan (financial statements) adalah dokumen bisnis yang digunakan perusahaan untuk melaporkan hasil aktivitasnya kepada berbagai kelompok pemakai yang dapat meliputi manajer, investor, kreditor, dan agen regulator.

Menurut PSAK 1 (2017), “Laporan Firmansyah dan Miyosi Margi Utami (2013), "SAK ETAP adalah Standar akuntansi untuk entitas yang memiliki skala kecil hingga menengah, misalnya UKM (tidak memiliki akuntabilitas publik)."

Menurut Ikatan Akuntansi Indonesia dalam buku Standar Akuntansi Keuangan Entitas Tanpa Akuntabilitas Publik (2016) menyatakan bahwa: SAK ETAP yaitu Standar Akuntansi Keuangan Entitas Tanpa Akuntabilitas Publik. Entitas tanpa akuntabilitas publik adalah entitas yang Tidak memiliki akuntabilitas publik yang signifikan. Menerbitkan laporan keuangan untuk tujuan umum (general purpose keuangan adalah penyajian terstuktur dari posisi keuangan dan kinerja keuangan suatu entitas. "Laporan keuangan merupakan dokumen yang digunakan oleh perusahaan untuk melaporkan aktivitas perusahaan kepada pemakai laporan keuagan seperti investor, kreditor dan lain-lain." Menurut Lilis Puspitawati dan Sri Dewi Anggadini (2011) dalam buku "Sistem Informasi Akuntansi", Siklus akuntansi secara garis besar menggambarkan proses pengidentifikasian bukti transaksi, pencatatan transaksi ke dalam jurnal umum (posting ke general ledger), pengelompokkan bukti-bukti transaksi ke dalam golongan transaksi yang sama ke dalam buku besar (ledger), 
meringkas bukti transaksi ke dalam neraca saldo (trial balance). Melakukan penyesuaian (adjustment), membuat kertas kerja (worksheet) dan membuat laporan keuangan (financial statement). Menurut Rudiyanto (2012), “Siklus akuntansi adalah urutan kerja yang harus dilakukan oleh akuntan sejak awal hingga menghasilkan laporan keuangan perusahaan. Menurut Dwi Martani (2012) dalam buku Akuntansi Keuangan Menengah, "SAK ETAP digunakan untuk entitas yang tidak memiliki akuntabilitas publik yang signifikan dalam menuyusun laporan keuangan untuk tujuan umum (general purpose financial statement). SAK ETAP (2016) Dalam menyajikan laporan keuangan yang diatur dalam paragraph 3.10-3.11, pos-pos material yang disajikan terpisah dalam laporan keuangan sedangkan yang tidak material digabungkan dengan jumlah yang memiliki sifat atau fungsi sejenis.

Penyajian laporan keuangan menurut SAK ETAP yakni Di dalam penyusunan neraca, SAK ETAP (2016) dalam paragraph 4.2 dan 4.4 mengatur beberapa informasi penting yang harus dijabarkan di dalam neraca. Informasi tersebut meliputi kas dan setara kas, Piutang usaha dan Piutang lainnya, persediaan, properti investasi, Aset tetap, Aset tidak berwujud, Utang usaha dan Utang lainnya, Aset dan Kewajiban pajak, Kewajiban diestimasi, dan Ekuitas. Bentuk penyajian Aset lancar dan Aset tidak lancar, Kewajiban jangka pendek dan Kewajiban jangka panjang harus disajikan dalam klasifikasi terpisah dalam neraca sesuai yang disebutkan paragraph 4.6-4.9, kecuali jika penyajian berdasarkan likuiditas memberikan informasi yang andal dan lebih relevan.Jika pengecualian tersebut diterapkan, maka semua Aset dan Kewajiban harus disajikan berdasarkan likuiditasnya.

SAK ETAP mengatur penjelasan mengenai laporan laba rugi tersebut dalam paragraph 5.2-.5.4. Laporan laba rugi merupakan laporan yang memasukkan semua pos penghasilan dan Beban yangdiakui dalam suatu periode kecuali SAK ETAP mensyaratkan lain. Informasi yang wajib disampaikan minimal mencakup hal-hal berikut, yakni Pendapatan, Beban keuangan, bagian laba atau rugi dari investasi yang menguntungkan metode Ekuitas, Beban pajak, laba atau rugi neto.SAK ETAP mengharuskan entitas menyajikan pos, judul dan sub jumlah lainnya pada laporan laba rugi jika penyajian tersebut 
403 AGREGAT: Jurnal Ekonomi dan Bisnis

Vol. 2, No. 2, September 2018

http://journal.uhamka.ac.id/index.php/agregat

p-ISSN: 2580-3360 e-ISSN: 2581-2874

DOI: 10.22236/agregat_vol1/is4pp399-411

Hal 399-411

relevanuntuk memahami kinerja keuangan entitas. Hal yang dilarang adalah entitas tidak boleh menyajikan atau mengungkapkan pos Pendapatan dan Beban sebagai "pos luar biasa", baik dalam laporan laba rugi maupun dalam catatan atas laporan keuangan.Laporan perubahan Ekuitas diperlukan untuk menyajikan laba atau rugi suatu entitas dalam suatu periode, pos Pendapatan dan Beban yang diakui secara langsung, pengaruh perubahan kebijakan akuntansi dan koreksi kesalahan yang diakui dalam periode tersebut, dan jumlah investasi serta jumlah dividen dan distribusi lain ke pemilik Ekuitas selama periode tersebut sesuai yang dijelaskan dalam paragaraf 6.2. Lebih lanjut dalam paragraph 6.4-6.5, disamping laporan perubahan Ekuitas, entitas wajib menyusun laporan laba rugi dan saldo laba.

Laporan ini berfungsi untuk menyajikan laba atau rugi entitas dan perubahan saldo laba untuk suatu periode pelaporan. Jika perubahan pada Ekuitas hanya berasal dari laba atau rugi, pembayaran dividen, koreksi kesalahan periode lalu, dan perubahan kebijakan akuntansi maka SAK ETAP memperbolehkan entitas hanya menerbitkan laporan laba rugi dan saldo laba menggantikan laporan laba rugi dan laporan perubahan Ekuitas. Informasi yang wajib disampaikan di dalam laporan laba rugi dan saldo laba meliputi saldo laba pada awal periode pelaporan, dividen yang diumumkan dan dibayarkan atau terutang selama periode, penyajian kembali saldo laba setelah koreksi kesalahan periode lalu, penyajian kembali saldo laba setelah perubahan kebijakan akuntansi, dan saldo laba pada akhir periode pelaporan.

SAK ETAP menyebutkan dalam BAB 7 mengenai laporan arus kas bahwa laporan arus kas menyajikan informasi perubahan historis atas kas dan setara kas, yang menunjukkan secara terpisah perubahan yang terjadi selama satu periode dari aktivitas operasi, investasi, dan pendanaan. Dalam paragraph 8.4 disebutkan bahwa secara normal urutan penyajian catatan atas laporan keuangan adalah suatu pernyataan bahwa laporan keuangan telah disusun sesuai dengan SAK ETAP. Ringkasan kebijakan akuntansi signifikan yang diterapkan. Informasi yang mendukung pos-pos laporan keuangan yang sesuai dengan urutan penyajian setiap komponen laporan 
keuangan dan urutan penyajian pos-pos tersebut.

\section{METODE PENELITIAN}

Didalam penulisan ini, penulis menggunakan beberapa metode penelitian, yaituMetode Observasi: Metode ini dilakukan dengan cara mengumpulkan data secara langsung dengan cara mengamati dan melaksanakan langsung terhadap obyek yang diteliti pada saat melakukan Accounting Service. Metode wawancara: Metode ini dilakukan dengan cara menggumpulkan data berupa mnegajukan pertanyaan langsung kepada informan untuk memperoleh informasi yang diharapkan.Metode kepustakaan: Metode ini dilakukan dengan cara mengumpulkan data ataupun informasi melalui buku-buku yang berkaitan dengan objek riset.

\section{HASIL DAN PEMBAHASAN}

Berikut merupakan interpretasi dari hasil penerapan penyusunan dan penyajian laporan keuangan CV SK berbasis SAK ETAP.Penyusunan laporan keuangan CV SK berdasarkan SAK ETAP CV SK dalam melakukan penyusunan laporan keuangan mengguanakan 2 aplikasi yaitu sejak awal berdiri sampai dengan tahun 2012 bulan April CV SK menggunakan aplikasi bookkeeping dan sejak tahun
2012 bulan Mei sampai dengan sekarang CV SK mengguanakan aplikasi accurate dengan tahapan yang dilakukan oleh $\mathrm{CV}$ SK dalam melakukan penyusunan laporan keuangan.

Tahap pertama, Tahap Transaksi (Transaksi Internal dan Eksternal). Pada tahapan ini CV SK melakukan Pencatatan atas transaksi yang telah dilakukan selama perusahaan beroperasi. Transaksi yang dimaksudkan adalah transaksi keuangan yangterjadi dan berpengaruh terhadap arus kas CV SK. Tahap kedua adalah tahap pencatatan Penjurnalan. Penjurnalan adalah aktivitas meringkas dan mencatat transaksi perusahaan di buku jurnal dengan menggunakan urutan tertentu berdasarkan dokumen dasar yang dimilik. CV SK melakukan pembukuan Jurnal Umum dari transaksi-transaksi yang sudah terjadi ke dalam aplikasi Accounting Software Accurate dan berdasarkan nomor urut faktur atau tanggal terjadinya transaksi.

\section{Tahap ketiga adalah Tahap} Pengikhtisaran. Neraca saldo adalah daftar akun-akun beserta saldonya pada suatu waktu tertentu. Neraca saldo CV SK dibuat pada akhir periode akuntansi. Setelah semua ayat jurnal penyesuain dibuat dan di posting ke buku besar, maka 
405 AGREGAT: Jurnal Ekonomi dan Bisnis

Vol. 2, No. 2, September 2018

http://journal.uhamka.ac.id/index.php/agregat

p-ISSN: 2580-3360 e-ISSN: 2581-2874

DOI: 10.22236/agregat_vol1/is4pp399-411

Hal 399-411

neraca saldo dibuat dari akun-akun buku besar dan dinamakan neraca saldo telah disesuaikan. Tahap keempat adalah tahap pelaporan keuangan. Laporan keuangan yang disusun pertama kali CV SK adalah laporan laba rugi. Laporan laba rugi memiliki 3 komponen yaitu komponen Pendapatan, Biaya, dan laba-rugi. Langkah selanjutnya adalah menyusun laporan neraca.Selanjutnya membuat laporan perubahan Modal, pada tahap ini CV SK tidak membuat laporan arus kas dan catatan atas laporan keuangan.Setelah mengetahui penyusunan laporan keuangan CV SK, Team KAP melakukan Accounting Service atau pembenaran pada laporan keuangan dari awal penyusunan sampai menjadi laporan keuangan karena laporan keuangan $\mathrm{CV}$ SK masih belum sesuai dengan SAK ETAP.

Dalam menyusun laporan keuangan CV SK Team KAP menggunakan Aplikasi Microsoft Exceldengan tahapantahapan yang dilakukan team KAP. Tahap pertama, Tahap Transaksi (Transaksi Internal dan Eksternal). Pada tahap ini Team KAP meminta bukti-bukti transaksi dan daftar akun yang dimilki oleh CV SK selama berjalannya aktivitasperusahaan dan menganalisa dan mengidentifikasi atas bukti transaksi tersebut. Tahap kedua, Tahap Pencatatan. Team KAP melakukan pembukuan atau menjurnal semua kegiatan atau transaksi-transaksi yang dilakukan selama setahun ke dalam Aplikasi excel.

\section{Tahap ketiga, Tahap}

Penggolongan.Setelah melakukan tahap pencatatan langkah selanjutnya adalah melakukan posting. Posting adalah aktivitas memindahkan catatan di buku jurnal ke dalam buku besar sesuai dengan jenis transaksi dan nama akun masingmasing. Pada tahap ini karna Team KAP menggunakan aplikasiMicrosoft Excel maka buku besar sudah langsung ter-link setelah melakukan penjurnalan dari buktibukti yang sudah di jurnal sebelumnya.Sedangkan untuk buku besar pembantu karena CV SK tidak membuat buku besar pembantu maka Team KAP membuat buku besar pembantu agar dapat mengetahui transaksi-transaski yang telah terjadi secara lebih detail. Team KAP membuat buku besar pembantu Piutang Penjualan, Hutang Dagang, dan Persediaan. Tahap keempat, Tahap Pengikhtisaran. Setelah melakukan tahap penggolongan yaitu mem-posting buku jurnal umum ke buku besar, langkah 
selanjutnya adalah membuat neraca saldo.

Neraca saldo adalah daftar akun-akun beserta saldonya pada suatu waktu tertentu.Biasanya, neraca saldo dibuat pada akhir periode akuntansi. Menyusun Ayat Jurnal Penyesuaian. Setelah semua ayat jurnal penyesuaian dibuat dan di posting ke buku besar, maka neraca saldo dibuat dari akun-akun buku besar dan dinamakan neraca saldo telah disesuaikan. Pada tahap ini karna Team KAP menggunakan aplikasi excel maka neraca saldo disesuaikan sudah langsung ter-link setelah melakukan posting buku jurnal umum ke buku besar.

Tahap kelima, Tahap Pelaporan Keuangan.Laporan keuangan yang disusun pertama kali adalah laporan neraca, yang terdiri dari Asset lancar, Asset tidak lancar, Liabilitas jangaka pendek dan Ekuitas. Laporan keuangan yang kedua adalah laporan laba rugi, yang terdiri dari Pendapatan, Beban, dan Pendapatan (Beban) lain. Pada tahap ini karena Team KAP menggunakan aplikasi excel, maka semua laporan tersebut sudah ter-link setelah membuat Neraca Saldo. Satu siklus akuntansi terdiri dari banyak fungsi yang dilakukan dalam rangka mengolah transaksi menjadi informasi keuangan. Dapat dibandingkan antara siklus akuntansi CV SK dan siklus akuntansi yang terdapat dalam SAK ETAP memiliki perbedaan, yaitu CV SK tidak membuat buku besar dan buku besar pembantu. CV SK tidak membuat laporan arus kas dan catatan atas laporan keuangan. Kendala yang dihadapi dalam menyusun laporan keuangan $\mathrm{CV}$ SK. Berikut adalah kendala pada saat melakukan penyusunan laporan keuangan pada CV SK yakni kesulitan pertama adalah pembukuan CV SK tidak lengkap, seperti tidak adanya buku pembantu kas dan setara kas, Piutang, dan Hutang. Sehingga dalam melakukan penjurnalan Team KAP harus melihat dari bukti-bukti transaksi seperti faktur penjualan, faktur pembelian, nota kredit, nota debit, bond pembelian barang, bukti pengeluaran kas kecil, besar, dan konsumen.

Kesulitan kedua adalah pada pencatatan CV SK ada beberapa akunakun yang memiliki perlakuan yang tidak sesuai dengan standar akuntasi yang berlaku dan yang dipelajari penulis di bangku perkuliahan. Seperti perlakuan akun kasbon, dan Piutang lain-lain terkait dengan deposit. Penyajian Laporan Keuangan CV SK menurut SAK ETAP. Pada pembahasan kali ini penulis membatasi Laporan Keuangan CV SK 
407 AGREGAT: Jurnal Ekonomi dan Bisnis

Vol. 2, No. 2, September 2018

http://journal.uhamka.ac.id/index.php/agregat

p-ISSN: 2580-3360 e-ISSN: 2581-2874

DOI: 10.22236/agregat_vol1/is4pp399-411

Hal 399-411

hanya pada Laporan Neraca dan Laba Rugi.Berikut adalah laporan keuangan yang telah dibuat oleh CV SK. Laporan Neraca, Neraca digunakan untuk menilai likuiditas, solvabilitas, dan fleksibilitas keuangan perusahaan.Neraca menyajikan Asset, Kewajiban, dan Ekuitas suatu entitas pada suatu tanggal tertentu akhir periode pelaporan. Neraca dikatakan seimbang apabila harta perusahaan atau Asset jumlahnya sama dengan jumlah Utang ditambah Modal $($ harta $=$ Utang + Modal).

Laporan Laba Rugi. Laporan laba rugi adalah laporan yang mengukur keberhasilan operasi perusahaan selama periode tertentu.Dalam laporan laba rugi CV SK terdiri dari Pendapatan penjualan, HPP Produksi, HPP service dan dekor, persediaan bahan baku, Biaya operasi dan Pendapatan dan Beban lain.Kebijakan Akuntansi CV SK. Dasar Penyusunan Laporan Keuangan, Pencatatan transaksi keuangan perusahaan disusun berdasarkan konsep harga perolehan (historical cost) dan accrual basic method.Dengan demikian dalam laporan keuangan ini tidak memperhatikan perubahan pada nilai sekarang (current value) dari AktivaAktiva tidak lancar perusahaan. Kas dan

Setara Kas, Kas merupakan alat pembayaran yang siap dan bebas dipergunakan untuk memBiayai kegiatan perusahaan, deposito berjangka yang akan jatuh tempo dalam waktu 3 bulan atau kurang dari tanggal perolehannya diklasifikasikan sebagai setara kas, begitu juga saldo rekening giro atau uang tunai yang dalam brankas diklasifikasikan setara kas.Piutang, Perusahaan tidak mencadangkan piutang tidak tertagih disebabkan manajemen berkeyakinan bahwa semua Piutang dapat tertagih.Piutang dihapuskan pada saat Piutang tersebut dipastikan tidak dapat ditagih lagi.

Persediaan, Harga perolehan barang jadi ditentukan dengan metode periodik Harga perolehan barang penunjang ditentukan dengan metode rata-rata bergerak.Penyisihan untuk penurunan nilai persediaan ditentukan berdasarkan penelaahan terhadap keadaan persediaan.Aktiva Tetap, Aktiva tetap diakui sebesar harga perolehan setelah dikurangi dengan akumulasi penyusutan.Semua Aktiva tetap disusutkan dengan menggunakan metode saldo garis lurus, selama masa 
manfaatnya.Gedung (20 tahun), peralatan (4 tahun), kendaraan (8 tahun), dan Inventaris (4 tahun). Biaya pemeliharaan rutin dan pemakaian di bebankan pada laporan laba rugi pada saat terjadinya pengeluaran dalam jumlah yang signifikan, dan yang meningkatkan manfaat Aktiva tetap. Apabila Aktiva tetap tidak dipergunakan lagi atau dijual, maka nilai tercatat dan akumulasi penyusutannya dikeluarkan dari laporan keuangan dan keuntungan atau kerugian yang dihasilkan diakui dalam laporan laba rugi pada tahun bersangkutan.Pendapatan dan Beban. Pendapatan penjualan diakui sebagai Pendapatan pada saat dilakukan penyerahan/ pengiriman barang kepada konsumen, sedangkan Beban diakui sesuai dengan masa manfaatnya (accrual basis) pada periode yang bersangkutan.Penyajian laporan keuangan menurut SAK ETAP (2016).

Pajak Penghasilan. Taksiran pajak penghasilan belum ditentukan berdasarkan taksiran laba kena pajak untuk tahun yang bersangkutan.Perusahaan tidak melakukan penangguhan pajak atas perbedaan waktu pengakuan Pendapatan dan Beban antara laporan keuangan untuk tujuan komersial dan pajak. Penyajian Laporan Keuangan CV SK berdasarkan SAK ETAP Laporan keuangan Neraca. Berikut adalah penjelasan dari informasi-informasi yang disajikan dalam laporan neraca menurut SAK ETAP yakni pada Aset CV SK yang dilaporkan belum memenuhi sebagian besar ketentuan SAK ETAP. Untuk penyajian Aset, dikarenakanAkun Kasbon.Akun Kasbon yang dimaksud CV SK merupakan kas sementara yang dikeluarkan untuk karyawan dalammenjalankan kegiatan operasional perusahaan dan harus direalisasi dikemudian hari.

Sedangkan pengertian yang sebenaranya akun kasbon ialah pinjaman pribadi untuk karyawan dengan memotong gaji karyawan setiap bulannya. Oleh karena itu Team KAP menyarankan untuk mengganti nama akun kasbon ini menjadi Kas Advance. Dan Jangka waktu realisasi Kas Advance maksimal 7 hari setelah realisasi agar controling mudah dilakukan.Perlakuan Piutang lain-lain terkait deposit gedung, karena pencatatan yang dilakukan sangat rumit dan memungkinkan terjadinya overstated (double pencatatan). Menurut SAK ETAP Piutang lain-lain yang terkait dengan deposit gedung seharusnya masuk ke akun deposit gedung. Tetapi pada pencatatan CV SK Piutang lain-lain terkait deposit 
409 AGREGAT: Jurnal Ekonomi dan Bisnis

Vol. 2, No. 2, September 2018

http://journal.uhamka.ac.id/index.php/agregat

p-ISSN: 2580-3360 e-ISSN: 2581-2874

DOI: 10.22236/agregat_vol1/is4pp399-411

Hal 399-411

gedung dimasukkan di akun Piutang lainlain. Oleh karena itu CV SK disarankan untuk memisahkan akun "Piutang lainlain" yang berkaitan dengan deposit gedung. Aktiva tetap yang disajiakan dalam laporan keuangan CV SK belum sesuai dengan SAK ETAP karena tidak adanya rincian Aktiva tetap yang lengkap seperti: tanggal perolehan yang sesungguhnya, akumulasi penyusutannya masih ada yang tidak disesuaikan pada beberapa bulan tahun berjalan.

Oleh karena itu Team KAP membuat daftar rincian penyusutan Aktiva Tetap yang lengkap terdiri dari Harga Perolehan, Tanggal perolehan, Masa Manfaat dan metode akuntansi keuangan penyusutan yang sesuai dengan standar akuntansi yang berlaku umum. Sehingga alokasi pembebanan Aktiva Tetap setiap tahunnya di posting dengan wajar ke dalam jurnal.Pada kewajiaban CV SK yang dilaporkan sudah memenuhi sebagian besar ketentuan SAK ETAP untukpenyajian Kewajiban,akan tetapi untuk Kewajiban CV SK karena Hutang dibagi menjadi 3 yaitu Hutang dagang, Hutang sewa peralatan service, Hutang sewa pelatan dekor. Maka Team KAP memutuskan untuk menggabungkan ke tiga Hutang tersebut menjadi Hutang dagang agar tidak terjadi kesalahan pencatatan atau double catat pada saat melakukan penjurnalan seperti tahuntahun sebelumnya. Laporan Laba RugiMenurut SAK ETAP, laporan laba rugi minimal mencakup pos Pendapatan, Beban keuangan, bagian laba atau rugi dari investasi yang menggunakan metode Ekuitas, Beban Pajak dan laba atau rugi neto. Penyajian Laporan Laba Rugi pada CV SK telah berdasarkan Standar Akuntansi yang berlaku.Pada SAK ETAP (2016) pengklasifikasian Beban dalam laporan laba rugi disajikan denganmenggunakan dua metode yaitu metode berdasarkan sifat Beban dan metodeberdasarkan fungsi Beban.

\section{SIMPULAN}

Berdasarkan hasil penelitian dan pengolahan data yang telah dilakukan, maka dapat diambil kesimpulan bahwa CV SK belum menyusun laporan keuangan lengkap menurut SAK ETAP. Dari semua siklus akuntansi, CV SKhanya menerapkan sebagian dalam penyusunan laporan keuangan. CV SK tidak membuat buku besar dan buku besar pembantu, serta tidak membuat laporan arus kas dan catatan atas laporan keuangan. Hal ini 
berdasarkan SAK ETAP yang menyaratkan laporan keuangan lengkap terdiri atas Neraca, Laporan Laba Rugi, Laporan Perubahan Ekuitas, Laporan Arus Kas, dan Catatan Atas Laporan Keuangan. Masalah-masalah yang dihadapi dalam menyusun laporan keuangan CV SK diantaranya adalah kurangnya pembukuan CV SK seperti buku pembantu Piutang, Hutang, dan Persediaan. Sehingga dalam proses penyusunan laporan keuangan ini sedikit memperlambat proses pengerjaan, karena Team KAP harus melihat dari bukti-bukti transaksi.Penyajian laporan keuangan CV SK sepenuhnya masih belum sesuai dengan standar akuntansi yang berlaku umum karena pada laporan neraca CV SK ini belum disusun berdasarkan SAK ETAP. Khususnya Aset CV SK yang dilaporkan belum sesuai dengan penyajian yang ada di SAK ETAP, yaitu seperti penyajian akun kasbon, Perlakuan Piutang lain-lain terkait deposit gedung, dan Aktiva tetap. Sedangkan untuk penyajian laporan laba rugi CV SK sudah sesuai dengan SAK ETAP.

\section{REFERENSI}

Dwi, Martani., dkk. (2012). Akuntansi Keuangan Menengah Berbasis
PSAK Buku 1. Jakarta: Salemba Empat.

Ikatan Akuntan Indonesia.(2017). Standar Akuntansi Keuangan. Jakarta: Salemba Empat.

(2016). Standar Akuntansi Keuangan Entitas Tanpa Akuntanbilitas Publik. Jakarta: Salemba Empat.

Kasmir. (2013). Analisis Laporan Keuangan.Edisi 1. Jakarta: Raja Grafindo.

Kieso, Donald E, Jerry J. Weygandt, Terry D. Warfield. (2011). Akuntansi Intermediate. Edisi Ketujuhbelas. Jilid Dua. Diterjemahkan oleh Emil Salim. Jakarta: Erlangga.P

Puspitawati Lilis, Sri Dewi Anggadini. (2011). Sistem Informasi Akuntansi. Yogyakarta: Graha ilmu.

Romney, Marshal B dan Paul John Steinbart. (2014). Sistem Informasi Akuntansi, Edisi ketiga belas, Diterjemahkan oleh: Kikin Sakinah, Nur Safira dan Novita Puspasari. Jakarta: Penerbit Salemba Empat.

Rudianto.(2012). Pengantar Akuntansi Konsep dan Teknik Penyusunan Laporan Keuangan. Jakarta: Penerbit Erlangga.

Ryan Ariefiansyah dan Miyosi Margi Utami.(2013). Membuat Laporan 
411 AGREGAT: Jurnal Ekonomi dan Bisnis Vol. 2, No. 2, September 2018

http://journal.uhamka.ac.id/index.php/agregat p-ISSN: 2580-3360 e-ISSN: 2581-2874

DOI: $10.22236 /$ agregat_vol1/is4pp399-411

Hal 399-411

Keuangan Gampang Untuk Pemula

dan Orang Awam. Jakarta Timur:

Dunia Cerdas.

Soemarso.(2009). Akuntansi Suatu

Pengantar.Buku ke 2.Edisi 5.

Jakarta: Salemba Empat.

T. Harrison Jr, Walter, T. Hongren,

Charles, Thomas, C. William,

Suwardy, Themin. (2012).

Akuntansi Keuangan. Edisi

Kedelapan. Erlangga.

Warren, James M Reeves \& Jonathan E.

Duchac.(2010). Pengantar

Akuntansi Adaptasi Indonesia. Edisi

25 .Jakarta : Salemba Empat. 